Journal of Economics and Behavioral Studies

Vol. 2, No. 4, pp. 131-137, Apr 2011

\title{
Equity Ownership and Financial Performance
}

\author{
Aman Srivastava \\ Jaipuria Institute of Management, Noida, India \\ amansri@hotmail.com
}

\begin{abstract}
This paper attempts to examine the relationship of equity ownership and financial performance of firms in India. The study explored the possibility that whether equity ownership type affects the financial performance of listed Indian firms. The study examined the relationship of equity ownership with accounting as well as market measures of financial performance of the firms. The study sampled the 500 listed companies constituting BSE 500 indices of Bombay Stock Exchange of India. The 397 most actively listed companies on BSE 500 indices of Bombay Stock Exchange of India, which constitute the bulk of trading, were chosen to constitute the sample of the study as of end of 2009-10. The study used Ordinary least square (OLS) to examine the relationship between the equity ownership and financial performance of the Indian listed firms. The findings of the study depict the presence of highly concentrated ownership structure in the Indian market. The results of the regression analyses interestingly indicate that the dispersed equity ownership influences certain dimensions of accounting financial performance measures (i.e. ROA and ROE) but not market performance measures (i.e. Tobin's $\mathrm{Q}$ P/E and P/BV ratios), which indicate that there might be other factors (Behavioral, macro economic, political, contextual) affecting firms performance other than ownership structure. The findings of the study might be relevant for practitioners and investors for taking their financing and investment decisions.
\end{abstract}

Keywords: Equity Ownership, Financial Performance, India

\section{Introduction}

Capital structure, equity ownership structure and its impact on financial performance of firms has always been a serious agenda for researches across the globe. Scholars across the world are putting efforts to understand the impact of capital structure and equity ownership on financial performance of the firms. What is the composition of debt and equity in capital structure of the firm and who owns the firm's equity and how does that affect financial performance of a firm has been a topic investigated by researchers for decades? The modern organization emphasizes the separation of management and ownership; in practice, the interests of group managing the company can vary from the interests of those that supply the capital to the firm. The review of literature has suggests that an immense attention to the ownership structure and financial performance of the firms. One of the biggest conflicts in any public limited company is not only between management and the shareholders but also between the controlling interest shareholders and non controlling interest shareholders. The share holders having controlling interest in a public limited company is able to influence the decisions of top management but the same luxury is not available with the smaller shareholders having non controlling interest in the company. This distribution of shareholders between shareholders having controlling and noncontrolling interest varies from company to company. In other words the equity ownership structure varies from company to company and that so the performance of the company varies from company to company depending upon the ownership distribution.

The available literature suggests that the majority of studies in this area focused on the issue corporate governance but only in some of the recent studies the scholars started focusing on the issue of ownership structure and firm performance. In Indian context very few studies focused on this aspect. This paper is a moderate attempt to examine the relationship of ownership structure and performance of firms in India. The rest of the paper is organized as follows: Section 2 discusses the literature review, where both theoretical and empirical studies on previous works are looked into. It also incorporates the corporate governance mechanism in India. In section 3, the methodology of this study is considered. Empirical results and discussions are made in section 4 , while section 5 concludes the study. 


\section{Literature Review}

The firm's equity and how does ownership affect firm value has been a topic investigated by researchers for decades; however, most of the studies in this context are conducted outside of India. The study failed to document any relevant study on the topic in Indian context. Fama and Jensen (1983 a \& b) addresses the agency problems and they explained that a major source of cost to shareholders is the separation of ownership and control in the modern corporation. Even in developed countries, these agency problems continue to be sources of large costs to shareholders. Demstez and Lehn (1985) argued both that the optimal corporate ownership structure was firm specific, and that market competition would derive firms toward that optimum. Because ownership was endogenous to expected performance, they cautioned, any regression of profitability on ownership patterns should yield insignificant results. Morck et al. (1988) by taking percentage of shares held by the board of directors of the company as a measure of ownership concentration and holding both Tobin's $Q$ and accounting profit as performance measure of 500 Fortune companies and using piece-wise linear regression, found a positive relation between Tobin's $Q$ and board ownership ranging from $0 \%$ to $5 \%$, a negative relation for board ownership ranging from $5 \%$ to $25 \%$, and again a positive relation for the said ownership above $25 \%$. It is argued that the separation of ownership from control for a corporate firm creates an agency problem that results in conflicts between shareholders and managers (Jensen and Meckling, 1976). The interests of other investors can generally be protected through contractual arrangements between the company and concerned stakeholders, leaving shareholders as the residual claimants whose interests can adequately be protected only through the institutions of corporate governance (Shleifer and Vishny, 1997).

Loderer and Martin (1997) analyzed the shareholding of insiders (i.e., director's ownership) as a measure of ownership. Taking the said measure as endogenous variable and Tobin's $Q$ as performance measure, they found (through simultaneous equation model) that ownership does not predict performance, but performance is a negative predictor of ownership. Pedersen and Thomsen (1997) examined the impact of ownership structure on company economic performance in the largest companies from 12 European nations. According to their findings the positive marginal effect of ownership ties to financial institutions is stronger in the market-based British system than in continental Europe. Cho (1998) found that firm performance affects ownership structure (signifying percentage of shares held by directors), but not vice versa. Lehmann and Weigand (2000) found that (1) the presence of large shareholders does not necessarily enhance profitability, and (2) the high degree of ownership concentration seems to be a sub-optimal choice for many of the tightly held German corporations. Their results also imply ownership concentration to affect profitability significantly negatively. Their empirical evidence suggests that representation of owners on the board of executive directors does not make a difference. Miwa and Ramseyer (2001) in their study of 637 Japanese firms and confirmed the equilibrium mechanism behind Demstez-Lehn. Demsetz and Villalonga (2001) examined the relation between the ownership structure and the performance (average Tobin's $Q$ for five years-1976-80) of the corporations if ownership is made multidimensional and also treated it as an endogenous variable. By using Ordinary Least Squares (OLS) and Two-stage Least Squares (2 SLS) regression model, they found no significant systematic relation between the ownership structure and firm performance.

In an interesting study by Lins (2000) investigated the relationship between management ownership structure, block share holders and the value of firm. He found that non management block shareholding is positively related with the value of any firm. In another study Lemmon and Lins (2003) studied the relationship between ownership structure and value of the firms in financial crisis. They found that the variables are negatively related. They found that ownership structure is an important determinant in the financial performance of any firm. Lauterbach and Tolkowsky (2004) attempted to study the relationship between controlling group shareholders and Tobin's $Q$ and they revealed that the value of Tobin's $Q$ maximizes if controlling interest goes above 67\%. Kaserer and Moldenhauer (2005) addressed the issue relationship of insider ownership and corporate performance and they revealed that there is positive and significant relationship between corporate performance and insider ownership. Kapopoulos and Lazaretou (2007) tried the model of Demsetz and Villalonga (2001) for 175 Greek firms for the year 2000 and found that higher firm profitability requires less diffused ownership structure. He also provides evidence that large non management block holders can mitigate the valuation discounts associated with the expected agency problem. 


\section{Data and Methodology}

The study aims to explore the effect of ownership structure on performance of a firm. It investigates whether the ownership type affects some key accounting measures ROE and ROA and market performance indicators Tobin's Q P/E and P/B of listed firms. It shows that there might be other reasons that have affected the performance of the listed companies of BSE 500, other than ownership structure. The data set consists of detailed trading and financial information and indicators about the 397 most actively traded BSE 500 listed companies on the Bombay Stock Exchange of India (BSE) during 2009-2010. The 397 companies cover a broad spectrum of sectors or industries totaling 18, which are: Finance, Oil \& Gas, Information Technology, Metal, Metal Products \& Mining, Capital Goods, FMCG, Transport Equipments, Power, Housing Related, Healthcare, Telecom, Diversified, Chemical \& Petrochemical, Miscellaneous, Media \& Publishing, Transport Services, Tourism, and Agriculture.

The main financial indicators obtained from the companies financial statements included Total Revenues or Turnover, Gross Profit, Net Income or Earnings After Taxes, Current Assets, Fixed Assets, Long Term Debt and Shareholders Equity. Finally, the third subset consists of companies' stock performance indicators obtained from CMIE PROWESS database including value traded, volume traded, number of transactions, market capitalization, market price as well as some calculated ratios using both CMIE PROWESS database as well as items reported in financial statements of sample companies such as debt to equity ratio, return on equity, return on assets, price earnings ratio and price to book value. The empirical investigation is conducted using known Ordinary Least Square Estimation methodology using both Return on Equity (ROE) and Return on Asset (ROA) variables - representing accounting performance measures, and Tobin's Q. Price-Earning Ratio (P/E) and Price to Book Value (P/BV) - representing stock market performance measures; separately as dependent variables. The following formula was used for modeling:

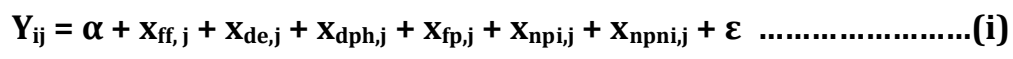

Where $\varepsilon \sim \operatorname{ND}\left(0, \sigma^{2}\right)$

$\mathbf{Y}_{\mathrm{ij}}$ : i corresponds to ROE, ROI, Q P/E or P/B for company $\mathrm{j}(\mathrm{j}=1 \ldots 397)$

$\mathbf{X}_{\mathrm{ff}, \mathrm{j}}$ : represents the percentage of free float in company $j$ capital structure,

$\mathbf{x}_{\mathrm{de}, j}$ : represents the debt to equity ratio for company $j$,

$\mathbf{x}_{\mathrm{dph}, \mathbf{j}}$ and $\mathbf{X}_{\mathrm{fp}, \mathrm{j}}$ : represents the domestic promoter and foreign promoter holding in the company

$\mathbf{x}_{\mathrm{npi}, \mathrm{j}}$ and $\mathbf{X}_{\mathrm{npni}, \mathrm{j}}$ : represents non promoter institutional and non promoter non institutional holding of the company.

The independent variables are represented by the percentage of Free Floated shares (FF), Debt to Equity ratio (D/E) and four variables representing promoters and non promoters' stake representing the ownership structure in sampled companies.

\section{Analysis and Results}

Inspection of ownership data reveals that the concentration of equity ownership in sampled 98 listed Indian firms of Bombay stock exchange of India Two measures of the structure of corporate ownership are used: the fraction of shares owned by a firm's promoters, (Indian and Foreign promoters' holding) and the fraction of shares owned by a non promoters (including all institutional and non institutional promoters). Table 1(a) and 1 (b) lists the frequency distribution of these measures of corporate ownership. The results suggests that promoter's holding ranges from 0 per cent to 99.33 per cent around a mean of 51.62 .0 per cent; non promoter share holding ranges from 0.67 per cent to 100 per cent around a mean of 47.25 per cent. 
Table 1(a): Frequency Distribution Measure of Ownership Structure

\begin{tabular}{lrrrrrr}
\hline & \multicolumn{3}{c}{ Promoters Holdings } & \multicolumn{3}{c}{ Non Promoters Holdings } \\
\cline { 2 - 7 } Range & Frequency & Percentage & Cumulative & Frequency & Percentage & Cumulative \\
\hline $0-10 \%$ & 10 & $2.48 \%$ & $2.48 \%$ & 5 & $1.24 \%$ & $1.24 \%$ \\
$10-20 \%$ & 5 & $1.24 \%$ & $3.71 \%$ & 20 & $4.95 \%$ & $6.19 \%$ \\
$20-30 \%$ & 33 & $8.17 \%$ & $11.88 \%$ & 49 & $12.13 \%$ & $18.32 \%$ \\
$30-40 \%$ & 57 & $14.11 \%$ & $25.99 \%$ & 63 & $15.59 \%$ & $33.91 \%$ \\
$40-50 \%$ & 80 & $19.80 \%$ & $45.79 \%$ & 85 & $21.04 \%$ & $54.95 \%$ \\
$50-60 \%$ & 83 & $20.54 \%$ & $66.34 \%$ & 87 & $21.53 \%$ & $76.49 \%$ \\
$60-70 \%$ & 63 & $15.59 \%$ & $81.93 \%$ & 55 & $13.61 \%$ & $90.10 \%$ \\
$70-80 \%$ & 47 & $11.63 \%$ & $93.56 \%$ & 27 & $6.68 \%$ & $96.78 \%$ \\
$80-90 \%$ & 19 & $4.70 \%$ & $98.27 \%$ & 5 & $1.24 \%$ & $98.02 \%$ \\
$90-100 \%$ & 7 & $1.73 \%$ & $100.00 \%$ & 8 & $1.98 \%$ & $100.00 \%$ \\
\hline
\end{tabular}

Table 1(b): Summary Statistics (\%)

\begin{tabular}{lccccc}
\hline & Mean & Maximum & Minimum & Std. Dev. & Observations \\
\hline PROMOTERS_HOLDING__ & 51.62 & 99.33 & 0.00 & 18.90 & 404 \\
NON_PROMOTERS_HOLDING_ & 47.25 & 100.00 & 0.67 & 18.33 & 404 \\
\hline
\end{tabular}

Table 2 shows the descriptive statistics of the sampled data. The distributions of these two variables are skewed. The coefficient of skewness for ownership structure is positive, implying that the distribution has a long right tail. To obtain a symmetric distribution, the raw data are converted to log values using the logistic transformation, i.e. log [percentage ownership/(100-percentage ownership)].

Table 2: Descriptive Statistics

\begin{tabular}{lcccccccc}
\hline & Q & RONW & ROCE & P_E & P_B & FF & PH & NPH \\
\hline Mean & 2.84 & 14.93 & 10.65 & 31.65 & 3.84 & 0.47 & 51.55 & 47.30 \\
Median & 1.63 & 16.68 & 9.27 & 19.69 & 2.54 & 0.50 & 51.12 & 48.50 \\
Maximum & 81.48 & 155.55 & 152.94 & 3535.28 & 101.80 & 1.00 & 99.33 & 100.00 \\
Minimum & -8.51 & -363.53 & -322.32 & -3212.36 & -40.15 & 0.05 & 0.00 & 0.67 \\
Std. Dev. & 5.29 & 27.22 & 23.21 & 282.07 & 7.51 & 0.18 & 19.02 & 18.45 \\
Skewness & 10.06 & -6.72 & -6.79 & 2.46 & 7.83 & 0.15 & -0.17 & 0.14 \\
Kurtosis & 134.06 & 98.82 & 112.44 & 118.75 & 101.11 & 2.78 & 3.04 & 3.13 \\
Probability & 0.00 & 0.00 & 0.00 & 0.00 & 0.00 & 0.31 & 0.39 & 0.43 \\
Observations & 397 & 397 & 397 & 397 & 397 & 397 & 397 & 397 \\
\hline
\end{tabular}

Table 3 gives the correlation matrix of the sampled data. In our sample, the correlation between the two measures of ownership concentration is -0.96 . This negative value indicates that many of the important shareholders are not defined as management shareholders since they have representation on corporate boards. The results suggest that accounting measures of firm's performance are significantly correlated with free float, non promoters' and promoters' holding of the sampled Indian firms. However the capital structure of the firms is not significantly correlated with any performance measure of the Indian firms. The markets measures of the firm performance $\mathrm{P} / \mathrm{E}$ and $\mathrm{P} / \mathrm{B}$ are also not significantly related with the ownership structure of the Indian firms. 
Table 3: Correlation Matrix

\begin{tabular}{|c|c|c|c|c|c|c|c|c|c|}
\hline & Tobin's Q & ROE & ROA & $\mathbf{P} / \mathbf{E}$ & $\mathbf{P} / \mathbf{B}$ & FF & $\mathbf{P H}$ & NPH & $\mathrm{D} / \mathrm{E}$ \\
\hline Tobin's Q & 1.00 & 0.22 & 0.20 & 0.04 & 0.36 & -0.16 & 0.18 & -0.18 & -0.02 \\
\hline$p$ & . & 0.00 & 0.00 & 0.44 & 0.00 & 0.00 & 0.00 & 0.00 & 0.73 \\
\hline ROE & 0.22 & 1.00 & 0.33 & -0.05 & 0.11 & 0.01 & 0.02 & -0.01 & -0.24 \\
\hline$p$ & 0.00 & & 0.00 & 0.36 & 0.02 & 0.90 & 0.75 & 0.79 & 0.00 \\
\hline ROA & 0.20 & 0.33 & 1.00 & -0.02 & 0.31 & -0.05 & 0.05 & -0.03 & -0.07 \\
\hline$p$ & 0.00 & 0.00 & & 0.70 & 0.00 & 0.33 & 0.28 & 0.59 & 0.16 \\
\hline $\mathrm{P} / \mathrm{E}$ & 0.04 & -0.05 & -0.02 & 1.00 & 0.38 & 0.00 & 0.02 & -0.02 & 0.00 \\
\hline $\mathrm{p}$ & 0.01 & 0.06 & 0.96 & 0.01 & 0.06 & 0.96 & 0.01 & 0.06 & 0.96 \\
\hline $\mathrm{P} / \mathrm{B}$ & 0.36 & 0.11 & 0.31 & 0.38 & 1.00 & -0.15 & 0.17 & -0.16 & -0.09 \\
\hline$p$ & 0.00 & 0.02 & 0.00 & 0.00 & & 0.00 & 0.00 & 0.00 & 0.07 \\
\hline $\mathrm{FF}$ & -0.16 & 0.01 & -0.05 & 0.00 & -0.15 & 1.00 & -0.87 & 0.87 & -0.04 \\
\hline$P$ & 0.00 & 0.90 & 0.33 & 0.94 & 0.00 & & 0.00 & 0.00 & 0.37 \\
\hline PH & 0.18 & 0.02 & 0.05 & 0.02 & 0.17 & -0.87 & 1.00 & -0.96 & 0.06 \\
\hline$p$ & 0.00 & 0.75 & 0.28 & 0.66 & 0.00 & 0.00 & & 0.00 & 0.25 \\
\hline $\mathrm{NPH}$ & -0.18 & -0.01 & -0.03 & -0.02 & -0.16 & 0.87 & -0.96 & 1.00 & -0.06 \\
\hline$p$ & 0.00 & 0.79 & 0.59 & 0.71 & 0.00 & 0.00 & 0.00 & & 0.25 \\
\hline $\mathrm{D} / \mathrm{E}$ & -0.02 & -0.24 & -0.07 & 0.00 & -0.09 & -0.04 & 0.06 & -0.06 & 1.00 \\
\hline$p$ & 0.73 & 0.00 & 0.16 & 0.98 & 0.07 & 0.37 & 0.25 & 0.25 & \\
\hline
\end{tabular}

Tables $4 \mathrm{a}$ and $4 \mathrm{~b}$ show the analysis of variance (ANOVA) of the variables. With F- values of 3.36 (sig 0.01), 6.48 (sig 0.00) and 2.80 (sig 0.03) for dependent variable Q, ROE and ROA and 3.97 (sig 0.00) for P/E and P/B as performance proxies respectively, it clearly shows that there is a strong relationship between all the performance measures with ownership structure of the company. The findings of the study clearly depicts that all accounting as well as market measures of the performance are significantly related with ownership structure of the Indian firms.

Table 4 (a): ANOVA Table (Q, ROE and ROA as Dependent Variable)

\begin{tabular}{ccccccr}
\multicolumn{2}{c}{ Tobin's Q as Dependent Variable } & \multicolumn{2}{c}{ ROE as Dependent Variable } & \multicolumn{2}{c}{ ROA as Dependent Variable } \\
F Value & Significance & F Value & Significance & F Value & Significance \\
\hline 3.36 & 0.01 & 6.48 & 0.00 & 2.80 & 0.13 \\
\hline
\end{tabular}

Table 4 (b): ANOVA Table (P/E and P/B as Dependent Variables)

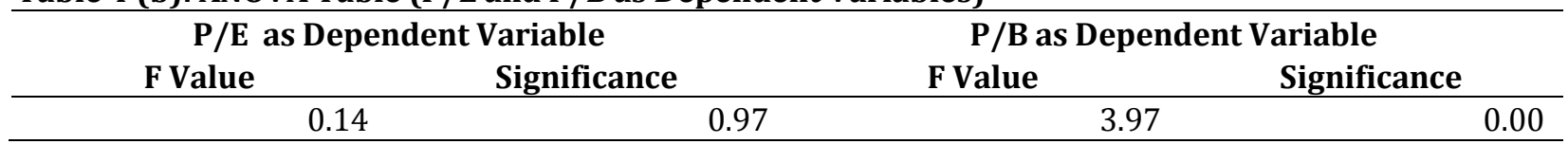

Table 5(a) and 5(b) show the results of the coefficient estimates. The coefficient of free float and promotors holding has positive relation with all the performance measures used in the study. But non promoters' holding and debt equity ratio has negative coefficient for $Q$ and ROE this indicates a negative relationship between these variables with $\mathrm{Q}$ and ROE. The findings clearly depict that all accounting measures of performance ROE and ROA of sampled firm are significantly related with ownership structure of the form while the market measures of firm's performance are not significantly related with the ownership structure of the firm. The findings of the study clearly indicate that as the Indian firms are more dominated by promoters' shareholder group and family owned business, the focus is more on the fundamentals of the firm rather than the market measures. 
Table 5 (a): Coefficient estimates ((Q, ROE and ROA as Dependent Variable)

\begin{tabular}{cccccccccc}
\hline Independent & \multicolumn{3}{c}{ Tobin's Q } & \multicolumn{3}{c}{ ROE } & \multicolumn{3}{c}{ ROA } \\
\cline { 2 - 10 } Variable & Beta & \multicolumn{1}{c}{ t } & $\mathbf{p}$ & Beta & \multicolumn{1}{c}{ t } & p & Beta & \multicolumn{1}{c}{ t } & p \\
\hline FF & 0.01 & 0.05 & 0.96 & 0.09 & 0.88 & 0.08 & -0.05 & -0.48 & 0.03 \\
PH & 0.12 & 0.64 & 0.52 & 0.09 & 0.49 & 0.02 & 0.37 & 1.94 & 0.05 \\
NPH & -0.07 & -0.34 & 0.73 & -0.02 & -0.08 & 0.03 & 0.37 & 1.94 & 0.05 \\
D/E & -0.03 & -0.56 & 0.57 & -0.25 & -5.01 & 0.00 & -0.07 & -1.47 & 0.14 \\
\hline
\end{tabular}

Table 5 (b): Coefficient estimates ((P/E and P/B)

\begin{tabular}{ccrrrrr}
\hline \multirow{2}{*}{ Independent Variable } & \multicolumn{3}{c}{$\mathbf{P} / \mathbf{E}$} & \multicolumn{3}{c}{$\mathbf{P} / \mathbf{B}$} \\
\cline { 2 - 7 } & \multicolumn{1}{c}{ Beta } & \multicolumn{1}{c}{ t } & \multicolumn{1}{c}{$\mathbf{p}$} & \multicolumn{1}{c}{ Beta } & \multicolumn{1}{c}{ t } & \multicolumn{1}{c}{$\mathbf{p}$} \\
\hline FF & 0.06 & 0.59 & 0.55 & 0.01 & 0.06 & 0.96 \\
PH & 0.08 & 0.41 & 0.68 & 0.17 & 0.91 & 0.36 \\
NPH & 0.01 & 0.03 & 0.98 & -0.01 & -0.03 & 0.98 \\
D/E & 0.00 & -0.06 & 0.95 & -0.10 & -2.07 & 0.04 \\
\hline
\end{tabular}

\section{Conclusion}

The significance of ownership characteristics and accounting performance measures i.e. ROA and ROE could be explained by the fact that the fundamental evaluation of companies, measured by, its financial indicators such as (ROA and ROE) are the most important factors used by investors in India to assess company's performance. In India, although earlier investors have culturally placed more emphasis on accounting performance measures, not stock market indicators, due to the fact that the Indian firms are largely closely held family owned business houses. Furthermore, these promoters groups always favored payment of dividends rather than stock price appreciation, due to more focus on fundamental factors rather than speculative market related factors. For that reason, the dividends yields paid by Indian companies are always very high compared to other emerging and developed markets. Thus the study did not consider dividend yield in the stock market indicators since it will be a distorted measure since issuers in India always pay a high dividends yield, sometimes, irrespective of earnings, since they are valued by investors according to dividends not price appreciation.

Furthermore, the type of ownership had an insignificant impact on stock market performance measures, which might imply that the stock performance was mainly affected by either economic and market conditions or speculative factors rather than ownership concentration. In addition, the results of this study could also be related to the market inefficiency of the Indian stock market and improper stock market valuation. The study concludes that certain time due to large foreign institutional investments and high liquidity the stock market performance measures may not be reliable. Therefore the accounting measures of performance of firms can directly be related with ownership structure of the firm than market measures. The study finally concludes that there is a significant relationship of accounting performance of the Indian firms with ownership structure of firms but market measures of the firm are not significantly with ownership structure of the Indian firms. 


\section{References}

Cho, M. H. (1998). Ownership Structure, Investment, and the Corporate Value: An Empirical Analysis. Journal of Financial Economics, 47(1): 103-121.

Demsetz, H. and Lehn, K. (1985). The Structure of Corporate Ownership: Causes and Consequences. Journal of Political Economy, 93(6): 1155-1177.

Demsetz, H. and Villalonga, B. (2001). Ownership Structure and Corporate Performance Journal of Corporate Finance, 7(3): 209-233.

Fama, E. F. and Jensen, C. M. (1983a). Agency Problems and Residual Claims. Journal of Law and Economics, 26(2): 327-349.

Fama, E. F. and Jensen, C. M. (1983b). Separation of Ownership and Control. Journal of Law and Economics, 26 (6): 301-325.

Jensen, C. M. and Meckling, W. (1976). Theory of the firm: managerial behavior, agency costs, and ownership structure. Journal of Financial Economics, 3: 305-360.

Kapopoulos, P. and Lazaretou, S. (2007). Corporate Ownership Structure and Firm Performance: Evidence from Greek Firms. Corporate Governance: An International Review, 15(2): 144-158.

Kaserer C. and Moldenhauer, B. (2005): Insider Ownership and Corporate Performance - Evidence from Germany. Working Paper, Center for Entrepreneurial and Financial Studies (CEFS) and Department for Financial Management and Capital Market.

Lauterbach, B. and Tolkowsky, E. (2004). Market Value Maximizing Ownership Structure when Investor Protection is Weak. Discussion Paper No. 8-200.

Lehmann, E. and Weigand, J. (2000). Does the governed corporation perform better? Governance structures and corporate performance in Germany. European Finance Review, 4: 157-195.

Lemmon, L. M. and Lins, V. K. (2003). Ownership Structure, Corporate Governance and Firm Value: Evidence from the East Asian Financial Crisis. The Journal of Finance, 8(4): 1445-1468.

Lins, K. (2000). Equity Ownership and Firm Value in Emerging Markets, Working paper, University of Utah.

Loderer, C. and Martin, K. (1997). Executive Stock Ownership and Performance Tracking Faint Traces. Journal of Financial Economics, 45(2): 595-612.

Miwa, Y. and Ramseyer, M. (2001). Does ownership matter? Discussion Paper, University of Tokyo.

Morck, R., Shleifer, A. and Vishny, R. (1988). Management Ownership and Market Valuation: An Empirical Analysis, Journal of Financial Economic 20: 293-315.

Pedersen, T. and Thompson, S. (1997). European Patterns of Corporate Ownership: A twelve country study, Journal of International Business Studies, 27: 759-778.

Shleifer, A. and Vishny, R. (1997). A survey of corporate governance. Journal of Finance, 52: 737-783.

Thomsen, S., \& Pedersen, T. (1998). Industry and Ownership Structure. International Review of Law and Economics, 18: 385-402. 